Александра Вранеш

Универзитет у Београду

821.163.41.09-6 Кочић П.

Филолошки факултет

Андрићев институт у Андрићграду

aleksandra.vranes@gmail.com

\title{
О КОЧИЋЕВОЈ ПРЕПИСЦИ
}

Кочићева преписка од најраније његове младости везане за школовање на страни, преко контаката са националним радницима до његове пуне књижевне комуникације са колегама по перу предмет је овог рада.

Кључне речи: Петар Кочић, преписка.

Кочићева писма доживљавам као литерарне есеје и као дневничко-мемоарску прозу. Она носе непосредност осећања, отвореност и непатворену искреност, било да су упућена оцу, девојци, супрузи, пријатељу, сараднику, уреднику, рецензенту, адвокату.

Кочићева преписка је дневнички прецизна, у белешкама о својој скромној свакодневици, скупљању претплате, службовању, путовању, страдању због српског рода и слободе. Хроничарски и мемоарски посвећено он записује важна дешавања у друштвеном и личном животу, из којих се неретко ишчитавају општа неправда и сопствена принципијелност.

Кочићеви националистички иступи током школовања и револуционарни испади у време његовог службовања, чак и онда када их нико није ни очекивао ни прижељкивао, на пример током сахрана, славских вечери и ручкова потврђивали су његов несаломив понос, самопоштовање и свест о сопственом идентитету, што се види и из његовог 
добронамерног савета његовој Милки у Јошавку, из Беча, 11.01.1903: „Имај увијек у очима да ћеш ти бити жена једног српског књижевника и будућег професора.“ (Кочић: 155) Кочићева емотивна преданост Милки избија из дамара сваког написаног ретка, али је реалистичност приказа будућег заједничког живота важнија од његове бриге да се управо из тих разлога које он наводи она за њега неће определити, jep, пише Кочић из Загреба Милки у Бањалуку, 25.05.1901: „треба да и ово знаш: да ћу ја можда и по затворима и апсанама провести већи дио свог живота, јер ћемо ми сви ђаци отпочети борбу против Швабе, који гули наш народ, отима му слободу и убија срећу.“ (Кочић: 147-148)

Шта се у материјалном смислу у Кочићевом животу променило од његове младости кад му је „новце за кошту, квартир и капут“ (Кочић: 128) слао отац Герасим Кочић из Гомионице, до зрелог доба, кад будући и сам отац, са једнаком пажњом и великим одрицањем, а још већим давањима, јер су многи од њега зависили, новце једва зарађује од свога литерарног умећа и посвећености? Слабо шта. У младићким писмима оца моли за летње хаљине, јер не може стално у зимском капуту ходити, у познијим писмима својој Милки, из Сарајева 29.01.1911, самопрегорно је обавештава да ће можда, због силне хладноће, морати капут купити, мада се све време труди да то не чини.“ (Кочић: 203) Његова немаштина очитује се из писма из Беча 3. децембра 1900. године: „Квартир нисам платио, газдарица љута, соба хладна, џепови пуни хартија - а трбух празан.“ (Кочић: 141) У истом писму брату Илији Кочићу он обавештава да је написао причу Туба и да ће је послати у Нову искру, јер се у Вили бојао цензуре. Истовремено, он позива брата да му шаље белешке како и шта се по народу прича. Ова Кочићева молба има чак и призвук инсистирања, јер му је очито било потребно подсећање на разговорни језик и на дневне згоде змијањских сељака. „Тјелесно и финансијално болестан" Кочић и у наредним писмима редовно 
свога брата Илију или своју драгу Милку извештава о новостима на књижевном плану: о Ђуриним зайисима који треба да буду објављени у Босанској вили (писмо од 8. марта 1901, из Беча); о причама $C$ йланине и исйоg йланине у издању друштва Зора. Кочић одржава уредну и љубазну преписку са књижевницима, критичарима, уредницима књижевних гласила: Марку Цару захваљује на „једрој и симпатичној рецензији (...) књижице $C$ йланине и исйоg йланине (...) у Срйском іласу“ и љути се због језуитске оцене Данила Живаљевића у Колу (9.02.1903); Гргуру Јакшићу саветује да се на француском шири истина о српској ствари (Беч, 19.04.1903. и 23.05.1903); Герасиму Ивезићу о слабостима његових критика (манастир Гомјеница, 3.07.1903); Вељку Петровићу, из Бањалуке 4.01.1907, захваљује на „пуној, топлој и импресивној пјесми“ њему намењеној (Кочић: 170); Карлу Пачуу шаље примерак Јазавиа йреg суgом (Бања Лука, 17.06.1909); Николи Кашиковићу о скупљању умотворина (Бања Лука, 2.09.1909); Петру Мирковићу о часопису Развитиак (Бања Лука, 5.10.1910).

Песнички дар и мисаоност присутни су у писмима. Поједине реченице доведене су до нивоа максима: „Желети вазда, а немати ништа од онога што се жели, човек пада у очајање, очајање собом доноси лудост, а лудост се свршава смрћу. Тако је са мном.“ (Кочић: 131) - пророчки у писму из младости као ученик шестог разреда Прве београдске гимназије закључује Кочић 23.03.1897. Подсећају на Божидара Кнежевића савети о животу, истини и правди које Кочић даје супрузи с њом се дописујући из Тузле 1908: „као што год у густој помрчини не можеш наћи свјетлости, исто ћеш тако узалуд у земљи без слободе тражити правде. Слобода је света и узвишена мајка Правде. Без слободе, без мајке своје, Правда се претвара у једну обичну курветину путару, која по широким царским друмовима трује и задржава 
невине, одузимајући им подмукло младост, свјежину и здравље.“(Кочић: 188)

Писма су и потврда пишчевог одушевљења славистичком и етнографском науком. Аутор писама се сећа рода, детињства и Змијања и отуда, и из комуникације са сељанима, црпи мотиве и за своје приче. Кочићева љубав према народу искрена је, дубока и природна, баш као и његова нервоза и раздражљивост, морална потиштеност и бунтовништво, помиреност са судбином проистеклом из судбине народа, социјална и национална побуна. У писмима се препознаје добра композиција приповедача. Животно, непосредно и пластично, здраво и трезвено судећи, Кочић сведочи о свом и животу свога народа и кроз своју преписку. А преписка подвлачи већ знану истину да му је и у животу и у књижевности добро народа било прече од личне користи.

\section{Извори и литература:}

Ивановић, Јован Н. „Окрупњавање и презентација Кочићеве преписке“. Кюижевна истиорија. - ISSN 0350-6428. - Год. 41, бр. 139 (2009): 787-800

Кочић, Петар. Прейиска, хронолоіија животиа и раgа, библиоірафија, рјечник. Прир. Драгољуб Влатковић, Бранко Милановић. Бањалука: Глас ; Сарајево: Свјетлост, 1986

Кочић, Петар. Сабрана gјела. Кю. 3. Прир. Никола Цветковић, Ненад Новаковић. Бањалука: Бесједа ; Београд: Ars libri, 2002 Максимовић, Горан. „Говор Кочићеве преписке“. Лейойис Майиие срйске. - ISSN 0025-5939. - Год. 180, књ. 474, св. 3 (септ. 2004): 334-349

Максимовић, Горан М. „Три необјављена Кочићева писма упућена из Беча Љубомиру Ковачевићу у Београд 1903. и 1904. године“. Philologia Mediana. - ISSN 1821-3332. - Год. 6, бр. 6 (2014): 497-504. 
Aleksandra Vraneš

\section{ABOUT KOČIĆ' CORRESPONDENCE}

Kočić' correspondence from his early childhood on the educational side, through contacts with national workers to its full literary communication with his colleagues is object of this work.

Key words: Petar Kočić, correspondence 